\section{Technical properties of beech wood from aged coppices in central Italy}

\author{
Angela Lo Monaco ${ }^{(1)}$, Luca Calienno ${ }^{(1)}$, Claudia Pelosi ${ }^{(2)}$, Federica \\ Balletti $^{(1)}$, Giorgia Agresti ${ }^{(2)}$, Rodolfo Picchio ${ }^{(1)}$
}

The aim of this study was to assess the features of timber from aged coppices in transition to high forests to provide a basis for their more efficient utilization. In the last decades, the abandonment of agricultural activities in mountain areas and the introduction of a territorial protection policy have led to a less intensive use of forests and the suspension of cuttings, which has resulted in the conversion of coppices into transitional high forests, now at the stage of thinning. In such condition, high-quality timber is difficult to obtain and wood supply is highly variable and hardly processable during manufacture. Two aged coppices of beech were selected in central Italy (Terminillo mountain, Rieti) and their wood specimens analyzed for several physical and mechanical characteristics: dry $\left(719-688 \mathrm{~kg} \mathrm{~m}^{-3}\right)$ and basic density $\left(585-560 \mathrm{~kg} \mathrm{~m}^{-3}\right)$; radial (7.06-7.17\%), tangential (12.43-11.72\%), and volumetric shrinkage (19.0518.51\%); axial compression strength (54.7-54.4 Mpa); static bending strength (100.9-108.4 MPa); and Brinell hardness $\left(29.8-27.7 \mathrm{~N} \mathrm{~mm}^{-2}\right)$. A colorimetric analysis was also carried out on wood specimens after aging treatments (light exposure up to 504 hours) using the CIELAB system. A set of equations was derived in order to predict the wood color characteristics as a function of the exposure time, and vice versa to assess the exposure time needed to obtain the desired color coordinates. Our results highlight that beech wood from aged coppices in central Italy has interesting qualitative features, suggesting a more profitable use of their wood than firewood.

Keywords: Coppice in Transition, Density, Shrinkage, Mechanical Properties, Brinell Hardness, Wood Colour, Fagus sylvatica L., Central Italy

\section{Introduction}

Coppice management has been deeply affected by economic and social changes in Europe since the 1950s. During the last century, the replacement of firewood with fossil fuels and the massive migration of people from mountain villages to towns has led to a change from traditional management of coppice to irregular coppicing or abandonment of management. Coppices have been progressively neglected in Italy (Ciancio et al. 2002, Picchio et al. 2009), and the suspension of their exploitation has produced "aged coppices", leading to alternative forms of traditional coppice management, such as the conversion to high forest systems (Amorini

et al. 1996). Conversion consists of thinning out the shoots from the aged coppices to produce a transitory high forest stand.

In the last 50 years, different approaches to coppice conversion have produced variable results in Europe, depending also on the stand conditions (Vogt et al. 2006, Van Calster et al. 2007, La Marca et al. 2009, Núñez et al. 2012, Suchomel et al. 2012, Altman et al. 2013, Pyttel et al. 2013, Szabó \& Hédl 2013). The transition towards a less intensive use of forests, which was considered more productive and more ecologically functional (Bagnaresi \& Giannini 1999), was also due to the introduction of policies aimed at a territorial protection (Ask \& Carlsson 2000,

(1) Department of science and technology for Agriculture, Forests, Nature and Energy, University of Tuscia, I-01100 Viterbo (Italy); (2) Department of Cultural Heritage Sciences, University of Tuscia , I-01100 Viterbo (Italy)

@ Angela Lo Monaco (lomonaco@unitus.it)

Received: Sep 23, 2013 - Accepted: Feb 15, 2014

Citation: Lo Monaco A, Calienno L, Pelosi C, Balletti F, Agresti G, Picchio R, 2015. Technical properties of beech wood from aged coppices in Italy. iForest 8: 82-88 [online 2014-06-04] URL: http://www.sisef.it/iforest/contents/?id=ifor1136-007

Communicated by: Giorgio Matteucci
Coppini \& Hermanin 2007, Bürgi et al. 2010, Hersperger \& Bürgi 2010). As a consequence, such forests were actively or passively converted into high forest stands, as their management switched to other goals, like timber production, biodiversity conservation, etc. Thus the transition to less intensive managing regimes with different environmental features is important, particularly for mountainous areas of the Mediterranean countries (Cañellas et al. 2004, Zagas et al. 2004, Decocq et al. 2005, Ciancio et al. 2006, La Marca et al. 2008, Lafortezza et al. 2013).

Coppices under natural evolution show a great structural variability, though a trend to conform to the typical structures of high forests is fairly clear. High forests have a prominent role in safeguarding biodiversity and promoting the non-productive functions of forests (Picchio et al. 2009, Ciancio \& Nocentini 2011). New silvicultural approaches are being applied to aged coppices with the aim of favoring their natural development, improving their stability and functionality, and enhancing their natural regeneration by seeds. As a result, coppice conversion is expected to increase further (Ciancio et al. 2002).

In Italy, coppices that are no longer exploited in the traditional way cover a large area. At present, aged coppices represent $89 \%$ of the whole Italian coppice surface area, and transitory high forests occupy about 150000 ha (IFNC 2007). On the Apennines (central Italy) beech usually grows at altitudes above 900-1000 m, though relict sites are located at lower altitudes, providing evidence for a larger diffusion in the past (Montelucci 1956, Anzalone 1961, 1980, Hofmann 1991). According to the Italian National Forest Inventory (IFNC 2007), beech forests cover approximately $1035107 \mathrm{ha}$, and coppices in conversion are more than 78000 ha, mainly located in the Apennines (61\%). Many state beech stands are currently in the transition phase from coppice to high forest.

A common question is: might the aging coppices be a cost-effective source of wood other than firewood? At present, the main product from coppices under conversion to high forests is firewood (Lo Monaco et al. 2011c, Picchio et al. 2011). In fact, coppices in transition produce a large amount of lowquality wood, i.e., branched and buckled stems, and discoloration of beech wood due to wounds, root die-back and dead branches is common (Torelli 1984, Knoke 2002, Vek et al. 2013). The red heartwood restricts the application of beech from coppices in transition to low-value products, with a consequent loss of financial value (Pöhler et al. 2006, Vek et al. 2013). It seems to be difficult to obtain high-quality timber from coppices in transition, and wood supply is 
Fig. 1 - Location of the aged coppice study areas in central Italy. The en-

larged map shows the territory of the Rieti province and the two sampled stands (black triangle: Fontenova; black circle: Prati di San Bartolomeo). Grey areas represent forests

(source: ISTAT 2011, Corine Land Cover 2006).

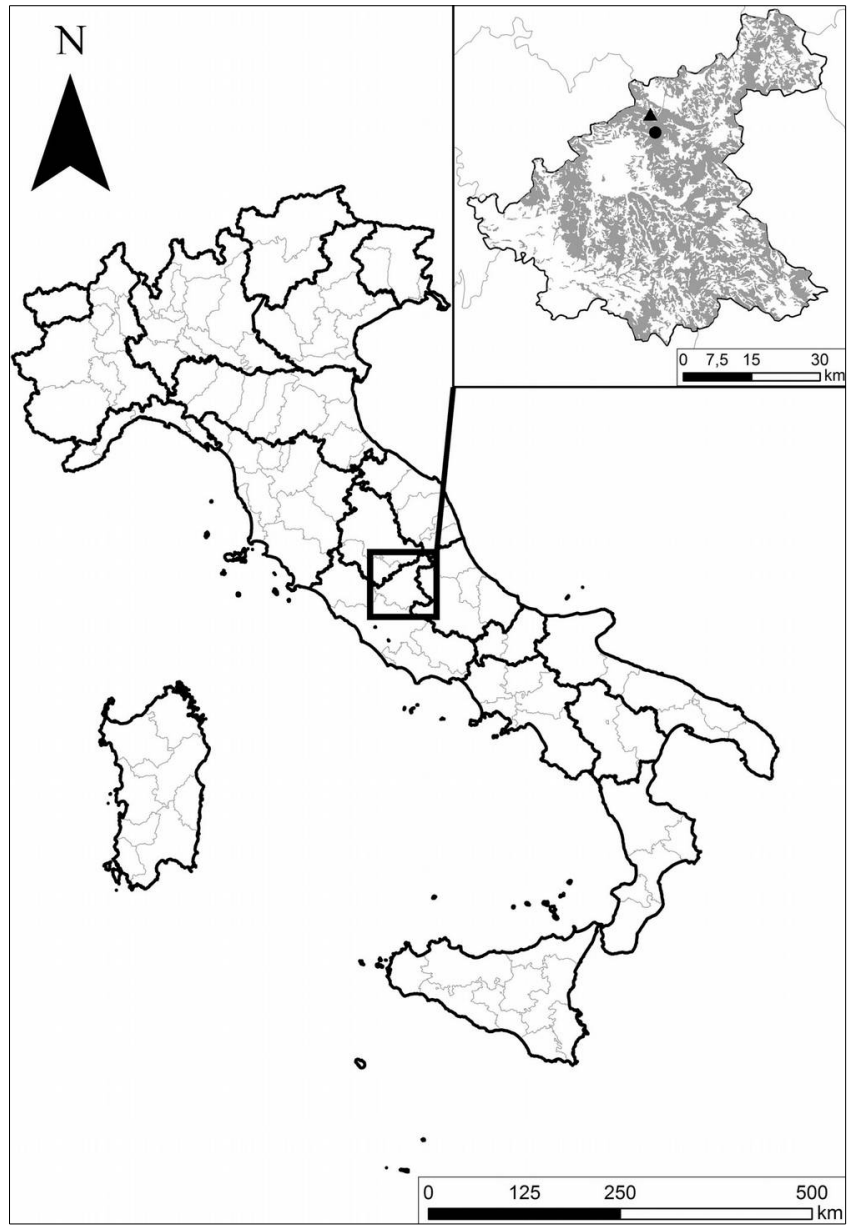

Tab. 1 - Main features of the two aged beech coppices in central Italy from which samples were taken. Values in parentheses are standard deviations. (DBH): diameter at breast height.

\begin{tabular}{lcc}
\hline Characteristics & Fontenova & Prati di San Bartolomeo \\
\hline Mean elevation (m a.s.l.) & 1460 & 1471 \\
Exposure & $\mathrm{N}$ & $\mathrm{S}-\mathrm{SE}$ \\
Mean slope (\%) & 30 & 40 \\
Soil & Middle clay soil. Deep soil & Middle clay soil. Deep soil \\
& with calcareous skeleton & with calcareous skeleton \\
Phyto-climate (Pavari) & Fagetum & Fagetum \\
Coordinates & $12^{\circ} 56^{\prime} 19^{\prime \prime}$ E / $42^{\circ} 32^{\prime} 51^{\prime \prime} \mathrm{N}$ & $12^{\circ} 56^{\prime} 43^{\prime}$ E $/ 42^{\circ} 30^{\prime} 41^{\prime}$ N \\
Mean tree age (years) & 120 & 100 \\
Mean DBH (cm) & $49(0.9)$ & $44(0.6)$ \\
Mean height (m) & $21(4.1)$ & $22(7.3)$ \\
Trees (n ha $\left.{ }^{-1}\right)$ & 520 & 550 \\
\hline
\end{tabular}

Tab. 2 - Main characteristics of the beech trees selected for sampling, and results of a comparison between the trees from each site (Mann-Whitney U-tests). (DBH): diameter at breast height.

\begin{tabular}{lcccc}
\hline Sampled stand & Tree & $\begin{array}{c}\text { Tree age } \\
\text { (year) }\end{array}$ & DBH (cm) & Height (m) \\
\hline Fontenova & 1 & 150 & 54 & 24 \\
& 2 & 135 & 50 & 22 \\
& 3 & 110 & 47 & 22 \\
& 4 & 97 & 45 & 20 \\
\hline Prati di & 1 & 130 & 58 & 23 \\
San Bartolomeo & 2 & 100 & 43 & 22 \\
& 3 & 85 & 40 & 18 \\
& 4 & 107 & 46 & 22 \\
\hline p-value & - & 0.248 & 0.386 & 0.758 \\
\hline
\end{tabular}

highly variable, making efficient processing during manufacture difficult. However, local public owners (e.g., Municipalities) would greatly benefit from a more profitable use of coppice wood.

In this paper, several physical and mechanical properties of beech wood from coppice converted into transitional high forest of central Italy were analyzed. Density, moisture shrinkage, dimensional shrinkage, and color variation were considered, and data obtained compared to literature. The potential uses of such wood for purposes other than energy production is also discussed.

\section{Materials and methods}

Two sites characterized by beech coppices converted into a transitional high forest were sampled on the Terminillo mountain (Leonessa Municipality, Rieti province, central Italy - Fig. 1): Fontenova (about $1460 \mathrm{~m}$ a.s.1.) and Prati di San Bartolomeo (about $1471 \mathrm{~m}$ a.s.1. - Tab. 1). Four trees from each site were randomly selected and felled; their main characteristics are displayed in Tab. 2. Log sections were collected from the whole tree at heights between 2 and $4 \mathrm{~m}$. Test specimens were prepared from the logs according to the general requirements for physical and mechanical tests (UNI-3252 1987). The logs and the specimens were conditioned at $65 \%$ relative humidity and $20^{\circ} \mathrm{C}$, to equilibrate at $12 \%$ moisture content.

In accordance with UNI ISO 3131 standard (UNI-ISO-3131 1985), basic and dry density were calculated on a set of 223 specimens $(20 \times 20 \times 30 \mathrm{~mm})$. Tangential, radial and volumetric shrinkage were calculated considering the total dimensional variation from the fully swollen to the oven dry condition on the 223 specimens. Samples were cut, dried, and measured according to UNI ISO 4469 and UNI ISO 4858 standards (UNI-ISO4469 1985, UNI-ISO-4858 1988). In addition, the coefficient of shrinkage was calculated for each variable measured as the shrinkage value when moisture content decreases by $1 \%$ below the fiber saturation point, under the assumption of a linear relationship (Lo Monaco et al. 2011c).

The compression strength $(\sigma y)$ was determined for a set of 231 specimens $(20 \times 20 \times 30$ $\mathrm{mm})$ at $12 \%$ moisture content, according to UNI ISO 3787 (UNI-ISO-3787 1985), and the bending strength $(\sigma b)$ was obtained for a set of 80 specimens $(20 \times 20 \times 30 \mathrm{~mm})$ at $12 \%$ moisture content, according to UNI ISO 3133 (UNI-ISO-3133 1985).

The resistance to indentation (formerly Brinell hardness) was quantified by the Brinell method for a set of 80 specimens $(50 \times 50 \times 40$ $\mathrm{mm}$ ) at $12 \%$ moisture content, according to UNI EN 1534 (UNI-EN-1534 2011).

Thirty samples were chosen for color analyses, and three measurements for each sample were performed after exposure to 0 , 
$1,2,3,4,5,6,7,8,9,10,11,12,24,48,72$, $96,120,144,168,216,312,408$ and 504 hours of irradiation carried out in a Model 1500E Solar Box (Erichsen Instruments). The system is equipped with a $2.5 \mathrm{~kW}$ xenon-arc lamp and a UV filter that cuts off the spectrum at $280 \mathrm{~nm}$. The samples were exposed in the Solar Box chamber at $550 \mathrm{~W}$ $\mathrm{m}^{-2}, 55^{\circ} \mathrm{C}$, with the UV filter at $280 \mathrm{~nm}$. The experimental conditions were chosen to simulate exposure to full sunlight.

Color was quantitatively characterized by an X-Rite CA 22 reflectance spectrophotometer. The characteristics of the color-measuring instrument are as follows: color scale CIEL*a*b*; illuminant D65; standard observer $10^{\circ}$; geometry of measurement $45^{\circ} / 0^{\circ}$; spectral range 400-700 $\mathrm{nm}$; spectral resolution $10 \mathrm{~nm}$; measurement diameter $4 \mathrm{~mm}$; and white reference supplied with the instrument. The CIELAB color system was used, where $L^{*}$ describes the lightness, while $a^{*}$ and $b^{*}$ describe the chromatic coordinates on the green-red and blue-yellow axes, respectively. The differences in lightness $\left(\Delta L^{*}\right)$, chromatic coordinates $\left(\Delta a^{*}\right.$ and $\left.\Delta b^{*}\right)$, and total color $\left(\Delta E^{*}\right)$ were then calculated using these parameters according to UNIEN-15886 (2010). The total color difference $\left(\Delta E^{*}\right)$ between two measurements $\left(L^{*} a^{*}{ }_{1}\right.$ $b *_{1}$ and $\left.L *_{2} a *_{2} b *_{2}\right)$ is the geometric distance between their positions in CIELAB color space. It is calculated as (eqn. 1):

$$
\Delta E^{*}=\left(\Delta L^{* 2}+\Delta a *^{2}+\Delta b^{*^{2}}\right)^{0.5}
$$

Statistical analysis was performed using the Statistica ${ }^{\circledR} 2007$ (StatSoft Inc., Tulsa, OK, USA) software package. ANOVA and MANOVA were applied when data were normally distributed; non-parametric KruskalWallis and Mann-Whitney U-tests (Sprent \& Smeeton 2001) were used when data were not normally distributed or showed a lack of homogeneity of variance after the Bartlett and Levene's test (Zar 1999). Differences among means were tested using the Tukey's HSD post-hoc test $(\alpha=0.05)$. Linear regres-

Tab. 3 - Physical properties of beech wood from aged coppices on the Terminillo mountain. Results of MANOVA and Tukey's tests applied to each parameter. (SD): standard deviation; (ns): non significant $(\mathrm{p}>0.05)$.

\begin{tabular}{lccccc}
\hline & \multicolumn{2}{c}{ Prati di San Bartolomeo } & \multicolumn{2}{c}{ Fontenova } & MANOVA \\
\cline { 2 - 5 } Property & $\begin{array}{c}\text { Sample } \\
\text { no. }\end{array}$ & $\begin{array}{c}\text { Average } \\
\text { value (SD) }\end{array}$ & $\begin{array}{c}\text { Sample } \\
\text { no. }\end{array}$ & $\begin{array}{c}\text { Average } \\
\text { value (SD) }\end{array}$ & $\begin{array}{c}\text { results } \\
\text { p-value }\end{array}$ \\
\hline $\begin{array}{l}\text { Dry wood density }\left(\mathrm{kg} \mathrm{m}^{-3}\right) \\
\text { Basic density }\left(\mathrm{kg} \mathrm{m}^{-3}\right)\end{array}$ & 124 & $719(41.9)$ & 99 & $688(40.6)$ & $<0.01$ \\
Radial shrinkage (\%) & 124 & $585(18)$ & 99 & $560(28.2)$ & $<0.05$ \\
Tangential shrinkage (\%) & 124 & $7.06(1.1)$ & 99 & $7.17(1.0)$ & $\mathrm{ns}$ \\
$\begin{array}{l}\text { Volumetric shrinkage (\%) } \\
\text { Radial shrinkage coefficient }\end{array}$ & 124 & $12.43(2.1)$ & 99 & $11.72(1.6)$ & $<0.05$ \\
$\begin{array}{l}\text { Tangential shrinkage } \\
\text { coefficient }\end{array}$ & 124 & $19.054(2.8)$ & 99 & $18.51(2.5)$ & $\mathrm{ns}$ \\
$\begin{array}{l}\text { Volumetric shrinkage } \\
\text { coefficient }\end{array}$ & 124 & $0.24(0.04)$ & 99 & $0.24(0.04)$ & $\mathrm{ns}$ \\
$\begin{array}{l}\text { Tangential and radial } \\
\text { shrinkage ratio }\end{array}$ & 124 & $1.78(0.07)$ & 99 & $0.39(0.05)$ & $<0.05$ \\
\hline
\end{tabular}

sion was applied on order to predict the variation of every chromatic coordinate $\left(L^{*}\right.$ or $a^{*}$ or $\left.b^{*}\right)$ as a function of the exposure time. Non-linear regression was used to predict the exposure time based on the three above chromatic coordinates.

\section{Results and discussion}

\section{Physical properties}

The physical properties of the beech wood from the two sites considered in this study are shown in Tab. 3. Significant differences between the two sites exist in dry density ( $p$ $<0.01)$, basic density $(\mathrm{p}<0.05)$, tangential shrinkage $(\mathrm{p}<0.05)$, and related coefficients $(p<0.05)$. Statistically significant differences in the physical properties of wood from the two sites are mainly due to density, which seems the factor underlying the differences observed for the other parameters.

Growth conditions and site ecological factors, in particular elevation, soil and climate, may determine variations in wood properties. In addition, tree age and ring width, which are affected by the managing practices, may influence wood physical proper- ties (Zobel \& Van Buijten 1989). Bouriaud et al. (2004) found a weak though significant correlation between stand density and ring width or ring age in beech. Indeed, each tree reacts independently to environmental and anthropic factors, thus determining the mechanical properties of its wood. Moreover, forestry interventions aimed at regulating the diametrical growth are discontinuous, leading to individual differences in growth.

The mean values of beech wood parameters obtained in this study were compared with values from the literature (Tab. 4). Dry density values were similar to the average values reported for beech wood from high forest stands in Italy (Giordano 1981, Cividini 1969), Greece (Skarvelis \& Mantanis 2013), France (CIRAD 2012), Hungary (Molnár et al. 2001) and Croatia (Sinković et al. 2011). Tsoumis (1991) gives a dry density value of $700 \mathrm{~kg} \mathrm{~m}^{-3}$ for beech of unknown provenance. Basic density values were also similar to the average value $\left(0.575 \mathrm{~g} \mathrm{~cm}^{-3}\right)$ of wood from coppice stands of beech in the northern Apennines (Berti et al. 1991). On the other hand, values of shrinkage were higher than those reported from beech wood in other

Tab. 4 - Physical and mechanical properties of beech wood derived from this study (last two columns) and from the literature. Measurement units were converted when necessary.

\begin{tabular}{|c|c|c|c|c|c|c|c|c|c|c|c|}
\hline Property & 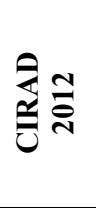 & 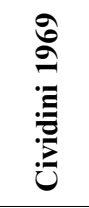 & 氧 & 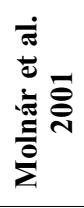 & 苞 & 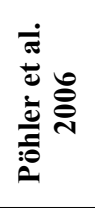 & 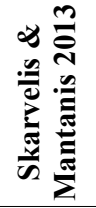 & 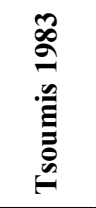 & 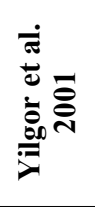 & 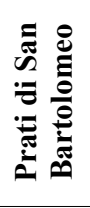 & 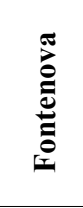 \\
\hline Dry wood density $\left(\mathrm{kg} \mathrm{m}^{-3}\right)$ & - & 669 & 690 & 712 & - & 695 & 640 & 700 & - & 719 & 688 \\
\hline Basic density $\left(\mathrm{kg} \mathrm{cm}^{-3}\right)$ & - & 547 & 610 & - & - & - & - & - & - & 585 & 560 \\
\hline Radial shrinkage (\%) & 5.7 & 5.55 & $2-5$ & 6.4 & 5.8 & - & 5.5 & 5.8 & 5.3 & 7.1 & 7.2 \\
\hline Tangential shrinkage (\%) & - & 14.27 & $9-20$ & 12.3 & 10.0 & - & 9.9 & 11.8 & 11.4 & 12.4 & 11.7 \\
\hline Volumetric shrinkage (\%) & - & 22.15 & - & 18.1 & 17.0 & - & 15.1 & - & - & 19.5 & 18.5 \\
\hline Tangential and radial shrinkage ratio & - & - & $2.3-2.9$ & - & - & - & - & - & - & 1.8 & 1.6 \\
\hline Compression strength $(\sigma y-\mathrm{MPa})$ & - & 51.7 & 61.0 & 63.6 & 58.0 & - & 55.4 & - & 54.2 & 54.7 & 54.4 \\
\hline Static bending strength $(\sigma b-\mathrm{MPa})$ & 111.0 & 108.1 & 118.0 & - & $68-149$ & 127.0 & 105.5 & 104.4 & 104.0 & 100.9 & 108.4 \\
\hline Brinell hardness $\left(\mathrm{Nmm}^{-2}\right)$ & - & - & - & 25.1 & - & 26.9 & - & - & - & 29.8 & 27.7 \\
\hline
\end{tabular}


Tab. 5 - Mechanical properties of beech wood from aged coppices on the Terminillo Moun tain, and results of MANOVA and Tukey tests applied to each parameter. (SD): standard deviation; (ns): not significant.

\begin{tabular}{lccccc}
\hline \multirow{2}{*}{ Property } & \multicolumn{2}{c}{ Prati di San Bartolomeo } & \multicolumn{2}{c}{ Fontenova } & MANOVA \\
\cline { 2 - 5 } & $\begin{array}{c}\text { Sample } \\
\text { no. }\end{array}$ & $\begin{array}{c}\text { Average } \\
\text { value (SD) }\end{array}$ & $\begin{array}{c}\text { Sample } \\
\text { no. }\end{array}$ & $\begin{array}{c}\text { Average } \\
\text { value (SD) }\end{array}$ & $\begin{array}{c}\text { results } \\
\text { p-value }\end{array}$ \\
\hline $\begin{array}{l}\text { Compression strength } \\
(\sigma y-\mathrm{MPa})\end{array}$ & 124 & 54.7 & 107 & 54.4 & $\mathrm{~ns}$ \\
$\begin{array}{l}\text { Static bending strengths } \\
(\sigma b-\mathrm{MPa})\end{array}$ & 40 & $\begin{array}{c}(5.3) \\
100.9\end{array}$ & 40 & 108.4 & $\mathrm{~ns}$ \\
$\begin{array}{l}\text { Brinell hardness } \\
\left(\mathrm{Nmm}^{-2}\right)\end{array}$ & 40 & $(19.9)$ & & $(13.5)$ & \\
\hline
\end{tabular}

parts of Europe (Nardi Berti 1993, Molnár et al. 2001, Yilgor et al. 2001, Sinković et al. 2011, CIRAD 2012, Skarvelis \& Mantanis 2013), but similar to values reported for Greece by Tsoumis (1983), and within the range reported by Giordano (1981) for the Italian beech.

The shrinking behavior of the wood is a key factor in many uses. As an anisotropic material, wood presents differential dimensional changes in the three anatomical directions. The tangential/radial shrinkage ratio measures the tendency for wood to split and warp when moisture content varies. The tangential/radial shrinkage ratio in the study site is lower than that of beech from other locations in Italy, resulting in greater stability (Giordano 1981), although the Terminillo's beech wood maintains the tendency to warp. This behavior is more similar to that of Carpinus betulus L. and Ostrya carpinifolia L. than to that of beech from coppiced forests in Italy (Berti et al. 1991). The tangential/radial shrinkage ratio of beech wood studied is also lower than that of wood from Turkey oak coppices in central Italy (Lo Mo-

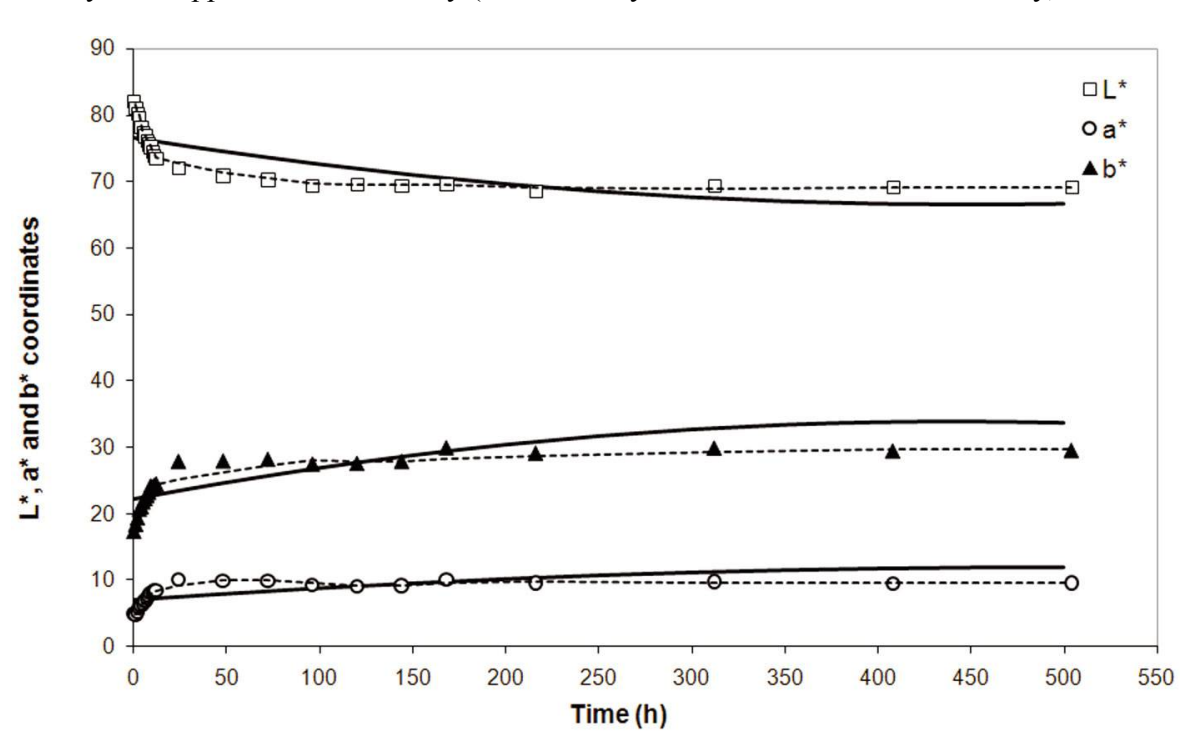

Fig. 2 - Changes in $L^{*}, a^{*}$ and $b^{*}$ values in beech wood from aged coppices due to light exposure in a Solar Box for up to 504 hours. The dotted lines represent the interpolated values from the rolling average $(L: \mathrm{n}=2 ; a: \mathrm{n}=2 ; b: \mathrm{n}=4)$; the solid lines are from the regression analysis in Tab. 6. naco et al. 2011c) and from Picconia azorica Tutin (Ferreira et al. 2012).

Sinković et al. (2011) showed that less shrinkage occurs in wood of higher density, but we found no correlation between density (oven dry condition or basic density) and shrinkage. Lo Monaco et al. (2011c) found a correlation between density and shrinkage in wood from Turkey oak coppices in central Italy. In this study, rings observed in transverse sections of beech wood are highly variable in width, likely due to several factors including tree age, silvicultural practices, site conditions etc. Therefore, even in beech coppices in transition, tree density is not necessarily a good estimator of wood quality, as already stated by Zhang et al. (1995).

\section{Mechanical properties}

The mechanical properties of beech wood from the sampled sites are shown in Tab. 5 . No significant differences in mechanical properties between sites were detected after ANOVA, with the exception of the Brinell hardness. This difference can be explained by the difference in wood density, and is in tected in color parameters between the two sites (Kruskall-Wallis test, $\mathrm{p}>0.05$ ); therefore, the two data sets were pooled together for further analysis.

Wood color coordinates before the aging treatment were: $L^{*}=82.06 \pm 0.60 ; a^{*}=4.92$ $\pm 0.15 ; b^{*}=17.36 \pm 0.53$ (Fig. 2). Such values are fairly similar to those reported for beech by Liu et al. (2005) and Todorović et al. (2012). Contrastingly, Miklečić et al. (2011) found a slightly darker color $\left(L^{*}=\right.$ $73.9 \pm 1.0)$.

Fig. 2 shows the variation in chromatic coordinates through time of treatment (light exposure). With increasing irradiation time, lightness $\left(L^{*}\right)$ clearly decreases, varying from 82.06 to 68.99 after 504 hours of exposure. The greatest change in lightness occurs within the first 48 hours of exposure, indicating a conspicuous darkening of the wood surface, and then $L^{*}$ reaches a steady state. Contrastingly, the parameters $a^{*}$ increased from 4.92 to 9.49 after 504 hours of irradiation, producing a slight change to red color in the treated material. Analogously, $b^{*}$ val- 
ues increased from $17.36(0 \mathrm{~h})$ to $29.57(504$ h) during light exposure. Similar trends in color changes were also described for Fagus crenata (Tolvaj et al. 2011).

Tab. 6 displays the results of the linear regression analysis carried out using the dependent variables $L^{*}, a^{*}, b^{*}$ as a function of the exposure time $(t)$. All the models and coefficients were highly significant, indicating that the three color coordinates may be predicted quite accurately $\left(\mathrm{R}_{\text {adj }}^{2}=0.49-0.68\right)$ based on the time to light exposure. Similarly, all the coefficient estimated by the regression analysis carried out for the dependent variable $t$ as a function of the three color coordinates were highly significant (Tab 7), suggesting that colorimetric parameters could be used to derive the exposure times of wood samples with a totally non-invasive approach.

Color changes were also ascertained using $\Delta E^{*}$ variations as functions of the time exposure to light (Fig. 3). After just 48 hours of exposure, $\Delta E^{*}$ reached the value 16.23 and then continued to increase by small increments to reach the value of 18.46 at the end of irradiation. The rapid decrease of lightness and the increase in the chromatic coordinates can be ascribed to photo-degradation processes, which were also observed for other broadleaved tree species (Agresti et al. 2013, Genco et al. 2011, Lo Monaco et al. 2011a, 2011b, Pelosi et al. 2013). The darker color indicates photo-degradation related to the decomposition of lignin due to the chromophore groups absorbing energy, especially in the UV part of the sunlight spectrum (Pandey \& Pitman 2003, Pandey 2005. George et al. 2005, Hon \& Shiraishi 2001).

\section{Conclusion}

The aim of this study was to assess the features of beech wood from aged coppices in central Italy to provide a basis for their more efficient and profitable exploitation.

Several physical and mechanical properties of beech wood from aged coppice from the study area were compared with information gathered from the literature. Beech wood from coppice in transition shows interesting qualitative characteristics, suggesting a more profitable use than firewood. Its mechanical properties make this material theoretically very attractive for industrial applications, such as in artifacts or floors. Moreover, the color analysis carried out on beech wood demonstrated that its characteristics are in the range reported for the species.

Nonetheless, defects exist that are a deterrent for the remunerative use of beech wood from aged coppices. For example, the red heartwood is an alteration making the wood from aged coppices unsuitable as industrial timber. Some physical parameters (e.g. shrinking) are also causes of concern, especially if the wood is not appropriately treated

Tab. 6 - Results of the three regression analyses for the dependent variables $L^{*}, a^{*}, b^{*}$ as a function of the light exposure time ( $t$, expressed in hours).

\begin{tabular}{llccccc}
\hline Variable & Parameter & Coefficient & p-value & $\mathbf{R}^{2}$-adj & Prob & Equation \\
\hline$L^{*}$ & Intercept & 76.615 & $<0.01$ & 0.541 & $<0.01$ & $L^{*}=76.615-0.045 t$ \\
& $t$ & -0.045 & $<0.01$ & & & $+0.00005 t^{2}$ \\
& $t^{2}$ & 0.00005 & $<0.01$ & & & \\
\hline$a^{*}$ & Intercept & 6.963 & $<0.01$ & 0.489 & $<0.01$ & $a^{*}=6.963+0.020 t$ \\
& $t$ & 0.020 & $<0.01$ & & & $-0.00002 t^{2}$ \\
& $t^{2}$ & -0.00002 & $<0.01$ & & & \\
\hline$b^{*}$ & Intercept & 22.19 & $<0.01$ & 0.684 & $<0.01$ & $b^{*}=22.19+0.053 t$ \\
& $t$ & 0.053 & $<0.01$ & & & $-0.00006 t^{2}$ \\
& $t^{2}$ & -0.00006 & $<0.01$ & & & \\
\hline
\end{tabular}

Tab. 7 - Regression analysis for the dependent variable $t$ (time) as a function of the $L^{*}, a^{*}$, $b^{*}$ color coordinates.

\begin{tabular}{lcc}
\hline Parameter & $\begin{array}{c}\text { Variable } \\
\text { coefficient }\end{array}$ & p-value \\
\hline Intercept & 10525.09 & $<0.01$ \\
$L^{*}$ & -256.27 & $<0.01$ \\
$a^{*}$ & 121.18 & $<0.01$ \\
$b^{*}$ & -111.61 & $<0.01$ \\
$L^{* 2}$ & 1.67 & $<0.01$ \\
$a^{* 2}$ & -11.27 & $<0.01$ \\
$b^{* 2}$ & 3.03 & $<0.01$ \\
$\mathrm{R}^{2}$ adj & 0.891 & $<0.01$ \\
Equation & $T=10525.09-256.27 L^{*}+121.18 a^{*}-111.61 b^{*+}$ \\
\hline
\end{tabular}

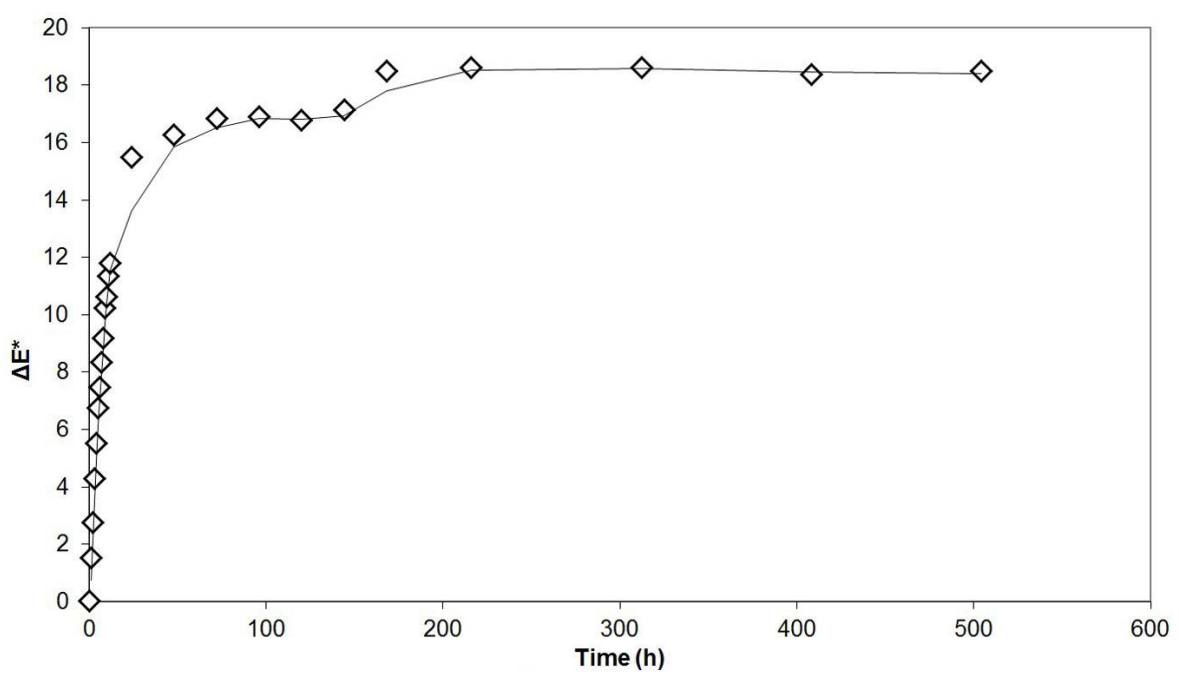

Fig. 3 - Changes in $\Delta E^{*}$ values in beech wood from aged coppices due to light exposure in a Solar Box for up to 504 hours.

during drying.

In the short term, silvicultural practices could increase the production of wood with good technological qualities in aged coppices, though some timber defects are likely related to previous silvicultural management. More suitable silvicultural techniques, applications and choices are needed when planning interventions, since forestry actions aimed at regulating tree growth can deeply affect wood properties.

\section{References}

Agresti G, Bonifazi G, Calienno L, Capobianco G, Lo Monaco A, Pelosi C, Picchio R, Serranti S (2013). Surface investigation of photo-degraded wood by colour monitoring, infrared spectroscopy, and hyperspectral imaging. Journal of Spectroscopy 1 (1): 1-13. - doi: 10.1155/2013/ 380536

Altman J, Hédl R, Szabó P, Mazurek P, Riedl V, Müllerová J, Kopecký M, Doležal J (2013). Treerings mirror management legacy: dramatic response of standard oaks to past coppicing in cen- 
tral Europe. PLoS ONE 8 (2): e55770. - doi: 10.1371/journal.pone. 0055770

Amorini E, Bruschini S, Cutini A, Di Lorenzo MG, Fabbio G (1996). Treatment of Turkey oak (Quercus cerris L.) coppices. Structure, biomass and silvicultural options. Annali Istituto Sperimentale Selvicoltura Arezzo 27: 105-111.

Anzalone B (1961). Sul limite altimetrico inferiore del faggio nella regione laziale [About the lower limit of altitude of the beech in the region Lazio]. Annali di Botanica 27: 80-109. [in Italian]

Anzalone B (1980). Escursione ai Monti Cimini [Excursion to the Cimini Mounts]. Atti e Resoconti Sociali, Informatore Botanico Italiano 12: 32-39. [in Italian]

Ask P, Carlsson M (2000). Nature conservation and timber production in areas with fragmented ownership patterns. Forest Policy and Economics 1: 209-223. - doi: 10.1016/S1389-9341(00)0001 6-2

Bagnaresi U, Giannini R (1999). La selvicoltura delle faggete: sintesi dello stato dell'arte [The silviculture of beech forests: a synthesis of the state of the art]. In: "Ecologia strutturale e funzionale di faggete italiane". Edagricole, Bologna, Italy, pp. 187-199. [in Italian]

Berti S, De Luca L, Edlmann Abbate L, Gambetta A, Orlandi E (1991). Per una migliore utilizzazione del legno ritraibile da bosco ceduo [For a better utilization of timber from coppice stands]. Contributi scientifico pratici, CNR IRL, Firenze, Italy, vol. 35, pp. 89-109. [in Italian with English abstract].

Bouriaud O, Bréda N, Le Moguédec G, Nepveu G (2004). Modelling variability of wood density in beech as affected by ring age, radial growth and climate. Trees - Structure and Function 18 (3): 264-276. - doi: 10.1007/s00468-003-0303-x

Bürgi M, Straub A, Gimmi U, Salzmann D (2010). The recent landscape history of Limpach valley, Switzerland: considering three empirical hypotheses on driving forces of landscape change. Landscape Ecology 25 (2): 287-297. - doi: 10.1007/s10980-009-9412-2

Cañellas I, Del Rio M, Roig S, Montero G (2004). Growth response to thinning in Quercus pyrenaica Willd. coppice stands in Spanish central mountain. Annals of Forest Science 61 (3): 243 250. - doi: 10.1051/forest:2004017

Ciancio O, Iovino F, Menguzzato G (2002). Prove sperimentali di avviamento a fustaia con il metodo del rilascio intensivo di allievi: i cedui di leccio in Aspromonte (Calabria). [Conversion in a high forest research with stand release: the Quercus ilex coppice in Aspromonte]. In: "Il bosco ceduo in Italia". Accademia di Scienze Forestali, Firenze, Italy, pp. 125-145. [in Italian with English abstract].

Ciancio O, Corona P, Lamonaca A, Portoghesi L, Travaglini D (2006). Conversion of clearcut beech coppices into high forests with continuous cover: a case study in central Italy. Forest Ecology and Management 224: 235-240. - doi: 10.101 6/j.foreco.2005.12.045

Ciancio O, Nocentini S (2011). Biodiversity con- servation and systemic silviculture: concepts and applications. Plant Biosystems 145 (2): 411-418. - doi: 10.1080/11263504.2011.558705

CIRAD (2012). TROPIX ${ }^{\circledR} 7$ - Bois tempérés: Hêtre. CIRAD, Montpellier, France, pp. 4. [online] URL: http://tropix.cirad.fr/FichiersComplementaires/FR/Temperees/HETRE.pdf

Cividini R (1967). Studio delle caratteristiche dei legnami per pavimenti e loro valutazione [Study of the characteristics of parquet woods and their evaluation]. Contributi scientifico pratici, Istituto Nazionale del legno, CNR, Roma, Italy, vol. 8, pp. 1-42. [in Italian with English abstract]

Cividini R (1969). Studio tecnologico sul faggio dell'Appennino Toscano [Study on wood technology of beech from Tuscan Apennine]. Contributi scientifico pratici, Istituto del Legno, CNR, Rome, Italy, vol. 12, pp. 1-38. [in Italian with English abstract]

Coppini M, Hermanin L (2007). Restoration of selective beech coppices: a case study in the Apennines, Italy. Forest Ecology and Management 249: 18-27. - doi: 10.1016/j.foreco.2007.04.035 Corine Land Cover (2006). CISIS - Centro Interregionale per i Sistemi informatici, geografici, statistici [Interregional Center for Geographical, Statistical, Information Systems]. Web site. [in Italian] [online] URL: http://www.centrointerregionale-gis.it/script/corinedownload.asp

Decocq G, Aubert M, Dupont F, Bardat J, WattezFranger A, Saguez R, Foucault B, Alard D, Delelis-Dusollier A (2005). Silviculture-driven vegetation change in a European temperate deciduous forest. Annals of Forest Science 62 (4): 313-323. - doi: 10.1051/forest:2005026

Ferreira RC, Lo Monaco A, Picchio R, Schirone A, Vessella F, Schirone B (2012). Wood anatomy and technological properties of an endangered species: Picconia azorica (Oleaceae). IAWA Journal 33 (4): 375-390. - doi: 10.1163/229419 32-90000101

Genco G, Lo Monaco A, Pelosi C, Picchio R, Santamaria U (2011). A study of colour change due to accelerated sunlight exposure in consolidated wood samples. Wood Research 56 (4): 511-524. [online] URL: http://www.woodresearch.sk/articles/4-20-140456 07pelosi.pdf

George B, Suttie E, Merlin A, Deglise X (2005). Photodegradation and photostabilisation of wood - the state of the art. Polymer Degradation and

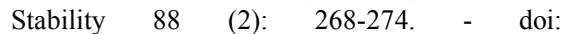
10.1016/j.polymdegradstab.2004.10.018

Giordano G (1981). Tecnologia del legno [Wood technology]. UTET, Torino, Italy, vol. 1, pp. 1255. [in Italian]

Hersperger AM, Bürgi M (2010). How do policies shape landscapes? Landscape change and its political driving forces in the Limmat Valley, Switzerland 1930-2000. Landscape Research 35 (3): 259-279. - doi: 10.1080/014263910037435 61

Hofmann A (1991). Il faggio e le faggete in Italia [Beech and beech forests in Italy]. Collana verde 81, Tipolitografia del CFS, Rome, Italy, pp. 140. [in Italian]

Hon DNS, Shiraishi N (2001). Wood and cellu- losic chemistry ( $2^{\text {nd }}$ edn). Marcel Dekker, New York, USA, pp. 928.

Horvat I (1969). Principal physical and mechanical properties of beech wood from the Zumberak, Petrova Gora, Senjsko Bilo and Velebit forest districts. Drewna Industrija 11-12: 183-277.

IFNC (2007). Inventario Nazionale delle Foreste e dei serbatoi forestali di Carbonio (anno di riferimento 2005) [National Inventory of Forests and Forest Carbon stock (reference year 2005)]. Ministero delle Politiche Agricole, Alimentari e Forestali, Rome, Italy, pp. 653. [in Italian]

ISTAT (2011). Basi territoriali e variabili censuarie [Territorial basis and census variables]. Istituto Nazionale di Statistica, Rome, Italy. [online] URL: http://www.istat.it/it/archivio/104317

Knoke T (2002). Value of complete information on red heartwood formation in beech (Fagus sylvatica). Silva Fennica 36 (4): 841-851. [online] URL: $\quad$ https://mediatum.ub.tum.de/doc/6849 69/300\%20Knoke.pdf

Lafortezza R, Sanesi G, Chen J (2013). Largescale effects of forest management in Mediterranean landscapes of Europe. iForest 6 (5): 342346. - doi: 10.3832/ifor0960-006

La Marca O, Marziliano P, Scopigno D (2008). Silvicultural options in ageing holm oak (Quercus ilex L.) coppices in Gargano: results after 14 growing seasons. Forest@ 5 (1): 318-336. [in Italian with English abstract] - doi: 10.3832 efor0552-0050318

La Marca O, Scopigno D, Tomaiuolo M (2009). Conversion trials in mixed coppices of Gargano (Puglia, Italy): first results. Forest@6 (1): 120128. [in Italian with English abstract] - doi: 10.3832/efor0573-006

Liu S, Loup C, Gril J, Dumonceaud O, Thibaut A, Thibaut B (2005). Studies on European beech (Fagus sylvatica L.). Part 1: variations of wood colour parameters. Annals of Forest Science 62 (7): 625-632. - doi: 10.1051/forest:2005063

Lo Monaco A, Marabelli M, Pelosi C, Picchio R (2011a). Colour measurements of surfaces to evaluate the restoration materials. In: Proceedings of the Conference "Optics for Arts, Architecture, and Archaeology III" (Pezzati L, Salimbeni R eds). Munchen (Germany) 23-26 May 2011. SPIE, Washington, vol. 8084, 80840P114. - doi: $10.1117 / 12.889147$

Lo Monaco A, Pelosi C, Picchio R (2011b). Colour evolution of wood surfaces in simulated sunlight exposure. In: Proceedings of the " $7^{\text {th }}$ Color Conference" (Rossi M ed). Rome (Italy) 15-16 Sep 2011. Quaderni di Ottica e Fotonica, Maggioli Editore, Santarcangelo di Romagna RN, Italy, vol. VII B, pp. 207-214.

Lo Monaco A, Todaro L, Sarlatto M, Spina R, Calienno L, Picchio R (2011c). Effect of moisture on physical parameters of timber from Turkey oak (Quercus cerris L.) coppice in Central Italy. Forestry Studies in China 13 (4): 276-284. - doi: 10.1007/s11632-013-0405-5

Miklečić J, Jirouš-Rajković V, Antonović A, Španić N (2011). Discolouration of thermally modified wood during simulated indoor sunlight exposure. BioResources 6 (1): 434-446. 
Molnár S, Németh R, Feher S, Tolvaj L, Papp G, Varga F (2001). Technical and technological properties of Hungarian beech wood consider the red heart. Wood Research 46 (1): 21-30.

Montelucci G (1956). Aspetti della faggeta depressa del Monte Fogliano [Aspects of the lowland beechwood in Fogliano Mountain]. Nuovo Giornale Botanico Italiano 63: 507-530. [in Italian] - doi: 10.1080/11263505609431628

Nardi Berti R (1993). La struttura anatomica del legno ed il riconoscimento dei legnami italiani di più corrente impiego [The anatomical structure and the identification of the Italian wood of greater use]. Contributi scientifico-pratici per una migliore conoscenza ed utilizzazione del legno, CNR, Firenze, Italy, pp. 155. [in Italian]

Núñez V, Hernando A, Velázquez J, Tejera R (2012). Livestock management in Natura 2000: a case study in a Quercus pyrenaica neglected coppice forest. Journal for Nature Conservation 20 (1): 1-9. - doi: 10.1016/j.jnc.2011.07.001

Pandey KK, Pitman AJ (2003). FTIR studies of the changes in wood chemistry following decay by brown-rot and white-rot fungi. International Biodeterioration and Biodegradadation 52: 151160. - doi: 10.1016/S0964-8305(03)00052-0

Pandey KK (2005). Study of the effect of photo-irradiation on the surface chemistry of wood. Polymer Degradation and Stability 90: 9-20. - doi: 10.1016/j.polymdegradstab.2005.02.009

Pelosi C, Agresti G, Calienno L, Lo Monaco A, Picchio R, Santamaria U, Vinciguerra V (2013). Application of spectroscopic techniques for the study of the surface changes in poplar wood and possible implications in conservation of wooden artefacts. In: Proceedings of the Conference "Optics for Arts, Architecture, and Archaeology IV" (Pezzati L, Targowski P eds). Munchen (Germany) 15-16 May 2013. SPIE, Washington, vol. 8790, 879014P1-14. - doi: 10.1117/12.2020418

Picchio R, Maesano M, Savelli S, Marchi E (2009). Productivity and energy balance in conversion of a Quercus cerris L. coppice stand into high forest in Central Italy. Croatian Journal of Forest Engineering 30 (1): 15-26. [online] URL: http://hrcak.srce.hr/index.php?show=clanak\&id_ clanak_jezik $=62219 \&$ lang $=e n$

Picchio R, Spina R, Maesano M, Carbone F, Lo Monaco A, Marchi E (2011). Stumpage value in the short wood system for the conversion into high forest of an oak coppice. Forestry Studies in China 13 (4): 252-262. - doi: 10.1007/s11632013-0411-7

Pöhler E, Klingner R, Künniger T (2006). Beech (Fagus sylvatica L.) - Technological properties, adhesion behaviour and colour stability with and without coatings of the red heartwood. Annals of Forest Sciences 63: 129-137. - doi: 10.1051/ forest:2005105

Pyttel P, Kunz J, Bauhus J (2013). Growth, regeneration and shade tolerance of the Wild Service Tree (Sorbus torminalis (L. ) Crantz) in aged oak coppice forests. Trees - Structure and Function
27 (6): 1609-1619 . - doi: 10.1007/s00468-0130908-7

Sinković T, Govorcin S, Sedlar T (2011). Comparison of physical properties of untreated and heat treated beech and hornbeam. Drvna Industrija 62 (4): 283-290. [online] URL: http://hrcak.srce.hr/index.php?

show $=$ clanak\&id_clanak jezik=111574\&lang=en

Skarvelis M, Mantanis G (2013). Physical and mechanical properties of beech wood harvested in the Greek public forests. Wood Research 58 (1): 1-7. [online] URL: http://www.wfdt.teilar.gr/ papers/Properties_of_beech_wood_harvested_in the_Greek_public_forests.pdf

Sprent P, Smeeton NC (2001). Applied nonparametric statistical methods ( $3^{\text {rd }}$ edn). Chapman \& Hall/CRC, London, UK, pp. 461.

Stoyanoff V, Entcheff E (1949). Comparative studies upon technological properties of the beech woods from Fagus sylvatica L. and Fagus orientalis Lippsky. Sbornik na Bõlgarskata Akademiye Naukite, Sofia, 40 (2): 222.

Suchomel C, Pyttel P, Becker G, Bauhus J (2012). Biomass equations for sessile oak (Quercus petraea (Matt.) Liebl.) and hornbeam (Carpinus betulus L.) in aged coppiced forests in southwest Germany. Biomass and Bioenergy 46: 722-730. doi: 10.1016/j.biombioe.2012.06.021

Szabó P, Hédl R (2013). Socio-economic demands, ecological conditions and the power of tradition: past woodland management decisions in a central European landscape. Landscape Research 38 (2): 243-261. - doi: 10.1080/01426397 .2012.677022

Todorović N, Popović Z, Milić G, Popadić, R (2012). Estimation of heat-treated beechwood properties by colour change. Bioresources 7 (1): 799-815.

Tolvaj L, Persze L, Albert L (2011). Thermal degradation of wood during photodegradation. Journal of Photochemistry and Photobiology B Biology 105: 90-93. - doi: 10.1016/j.jphotobiol.2 011.07.005

Torelli N (1984). The ecology of discoloured wood as illustrated by beech (Fagus sylvatica L.). IAWA Bulletin 5 (2): 121-127. - doi: 10.116 3/22941932-90000875

Tsoumis G (1983). Structure, properties and utilization of wood. Aristotelian University of Thessaloniki, Thessaloniki, Greece, pp. 655. [in Greek]

Tsoumis G (1991). Science and technology of wood. Chapman \& Hall, London, UK, pp. 494.

UNI-3252 (1987). Wood. General requirements for physical and mechanical tests. Ente Nazionale Italiano di Unificazione, Milan, Italy, pp. 8.

UNI-EN-1534 (2011). Wood flooring. Determination of resistance to indentation. Ente Nazionale Italiano di Unificazione, Milan, Italy, pp. 12.

UNI-EN-15886 (2010). Conservation of cultural property - Test methods - Colour measurement of surfaces. Ente Nazionale Italiano di Unificazione, Milan, Italy, pp. 16

UNI-ISO-3131 (1985). Wood. Determination of density for physical and mechanical tests. Ente Nazionale Italiano di Unificazione, Milan, Italy, pp. 4.

UNI-ISO-3133 (1985). Wood. Determination of ultimate strength in static bending. Ente Nazionale Italiano di Unificazione, Milan, Italy, pp. 4.

UNI-ISO-3787 (1985). Wood. Determination of ultimate stress in compression parallel to grain. Ente Nazionale Italiano di Unificazione, Milan, Italy, pp. 4.

UNI-ISO-4469 (1985). Wood. Determination of radial and tangential shrinkage. Ente Nazionale Italiano di Unificazione, Milan, Italy, pp. 4.

UNI-ISO-4858 (1988). Wood. Determination of volumetric shrinkage. Ente Nazionale Italiano di Unificazione, Milan, Italy, pp. 6.

Van Calster H, Baeten L, De Schrijver A, De Keersmaeker L, Rogister JE, Verheyen K, Hermy M (2007). Management driven changes (19672005) in soil acidity and the understorey plant community following conversion of a coppicewith-standards forest. Forest Ecology and Management 241 (1-3): 258-271. - doi: 10.1016/j.foreco.2007.01.007

Vek V, Oven P, Poljanšek I (2013). Content of total phenols in red heart and wound-associated wood in beech (Fagus sylvatica L.). Drvna Industrija 6 (1): 25-32. - doi: 10.5552/drind.2013. 1224

Vogt J, Fonti P, Conedera M, Schröder B (2006). Temporal and spatial dynamic of stool uprooting in abandoned chestnut coppice forests. Forest Ecology and Management 235 (1-3): 88-95. doi: 10.1016/j.foreco.2006.08.008

Yilgor N, Unsal O, Kartal SN (2001). Physical, mechanical, and chemical properties of steamed beech wood. Forest Products Journal 51 (11-12): 89-93. [online] URL: http://cat.inist.fr/?aModele $=$ afficheN\&cpsidt $=13397390$

Zagas TD, Ganatsas PP, Tsitsoni TK, Tsakaldimi M (2004). Thinning effect on stand structure of holm oak stand in northern Greece. In: Proceedings of the " $10^{\text {th }}$ MEDECOS Conference 2004" (Arianoutsou M, Papanastasis VP eds). Rhodes (Greece) 25 Apr - 1 May 2004. Millpress, Rotterdam, The Netherlands, pp. 1-9.

Zar JH (1999). Biostatistical analysis (4 $4^{\text {th }}$ edn). Prentice Hall, Upper Saddler River, NJ, USA, pp. 662.

Zhang SY, Owoundi RE, Nepveu G, Mothe F (1995). Modelling wood shrinkage and simulating the silvicultural influence in European oak (Quercus petraea and Quercus robur). Holzforschung 49: 35-44. - doi: 10.1515/hfsg.1995.49. 1.35

Zobel BJ, Van Buijten JP (1989). Wood variation: its causes and control. Springer-Verlag, Berlin, Heidelberg, New York, pp. 363. 